\title{
Synthesis and biological analysis of novel glycoside derivatives of $L-A E P$, as targeted antibacterial agents
}

Article

Accepted Version

Creative Commons: Attribution-Noncommercial-No Derivative Works 4.0

Bovill, R., Evans, P. G., Howse, G. L. and Osborn, H. M. I. (2016) Synthesis and biological analysis of novel glycoside derivatives of L-AEP, as targeted antibacterial agents.

Bioorganic \& Medicinal Chemistry Letters, 26 (15). pp. 37743779. ISSN 0960-894X doi:

https://doi.org/10.1016/j.bmcl.2016.05.052 Available at https://centaur.reading.ac.uk/65664/

It is advisable to refer to the publisher's version if you intend to cite from the work. See Guidance on citing.

To link to this article DOI: http://dx.doi.org/10.1016/j.bmcl.2016.05.052

Publisher: Elsevier

All outputs in CentAUR are protected by Intellectual Property Rights law, including copyright law. Copyright and IPR is retained by the creators or other copyright holders. Terms and conditions for use of this material are defined in the End User Agreement. 


\section{CentAUR}

Central Archive at the University of Reading

Reading's research outputs online 


\title{
Synthesis and biological analysis of novel glycoside derivatives of L-AEP, as targeted antibacterial agents
}

Richard Bovill ${ }^{\mathrm{a}}$, Philip G. Evans ${ }^{\mathrm{b}}$, Gemma L. Howse ${ }^{\mathrm{b}}$ and Helen M.I. Osborn ${ }^{\mathrm{b} *}$

${ }^{a}$ Thermofisher Scientific., Wade Road, Basingstoke, Hampshire. RG24 8PW, UK

${ }^{b}$ Reading School of Pharmacy, University of Reading, Whiteknights, Reading. RG6 6AD, UK

\begin{abstract}
To develop targeted methods for treating bacterial infections, the feasibility of using glycoside derivatives of the antibacterial compound L- $R$-aminoethylphosphonic acid (L-AEP) has been investigated. These derivatives are hypothesized to be taken up by bacterial cells via carbohydrate uptake mechanisms, and then hydrolysed in situ by bacterial borne glycosidase enzymes, to selectively afford L-AEP. Therefore the synthesis and analysis of ten glycoside derivatives of L-AEP, for selective targeting of specific bacteria, is reported. The ability of these derivatives to inhibit the growth of a panel of Gram-negative bacteria in two different media is discussed. $\beta$-Glycosides (12a) and (12b) that contained L-AEP linked to glucose or galactose via a carbamate linkage inhibited growth of a range of organisms with the best MICs being $<0.75 \mathrm{mg} / \mathrm{ml}$; for most species the inhibition was closely related to the hydrolysis of the equivalent chromogenic glycosides. This suggests that for (12a) and (12b), release of L-AEP was indeed dependent upon the presence of the respective glycosidase enzyme.
\end{abstract}

\section{Graphical abstract}

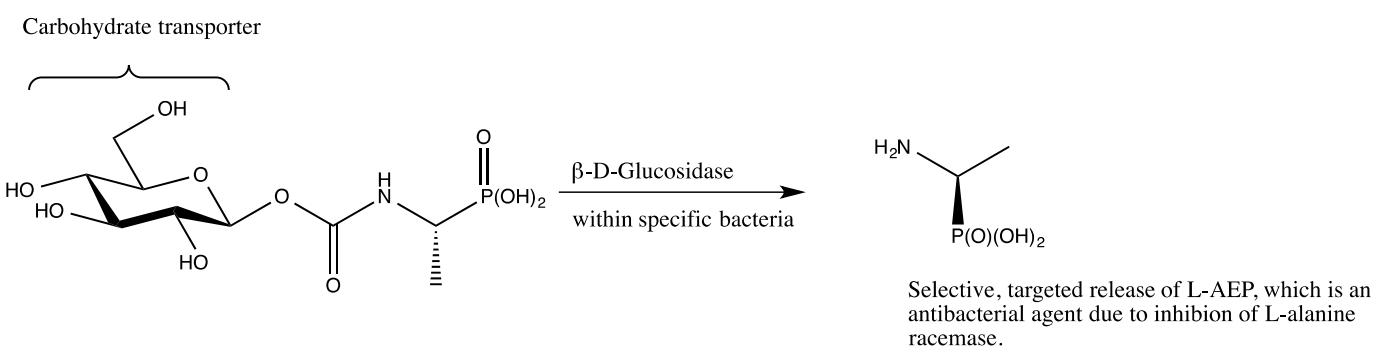


With the emergence of 'super bugs' such as MRSA, and the ever-increasing resistance of bacteria to many of the available antibacterial treatments, it is evident that new initiatives are needed to find alternative methods to treat bacterial infections. ${ }^{1}$ One such strategy is to target processes that are unique to bacteria as a way of developing selective antibacterial agents. ${ }^{2}$ In this regard, the bacterial enzyme alanine racemase which catalyses the interconversion of Lalanine to D-alanine is a useful target enzyme, since it is ubiquitous within bacteria, but is not present within humans. ${ }^{3}$ Inhibitors of L-alanine racemase are well documented, ${ }^{4}$ for example L- $R$-aminoethylphosphonic acid (L-AEP) ${ }^{5}$ forms a stable external aldimine which locks the enzyme in an unreactive state which eventually leads to bacterial cell wall disruption and cell death. ${ }^{6}$ However, L-AEP is ineffective as an antibacterial agent due to its poor uptake by bacteria. Attempts to enhance the uptake of the agent by bacteria have been reported, for example L-AEP has been linked to an amino acid, to form a dipeptide analogue, to allow active uptake into the bacterial cell via a peptide permease uptake system. Once inside the cell the peptide bond is cleaved by an appropriate amido-hydrolase, releasing the toxic L-AEP moiety. ${ }^{7}$ Examples of systems modified in this way were first reported by Roche in the 1970's with L-alanyl-AEP being brought to the market as alafosfalin ${ }^{8}$. However, alafosfalin was found to suffer from a number of major drawbacks including the occurrence of mutants defective in the peptide permease mechanism (around 1 in $10^{6}$ ) and the rapid development of resistant populations. ${ }^{9}$ Moreover, peptidase enzymes are widespread within serum and the gastrointestinal tract and hydrolysis of the peptide derivatives occurred before the agent reached the target site, limiting its applications within humans and animals to the treatment of urinary tract infections. ${ }^{9 a}$ In addition, it was observed that uptake of the compound into the bacterial cell was competitively inhibited by other peptides.

To overcome these limitations, alternative and more effective uptake and release systems are required. In this paper we present our studies that have investigated glycoside derivatives of L-AEP for inhibiting the growth of a range of bacteria. We hypothesise that linking L-AEP to 
a glycoside will produce L-AEP glycosides that are readily taken into the bacterial cell via active carbohydrate transport mechanisms. ${ }^{10,11,12}$ Once inside the cell, it is hypothesized that glycosidase enzymes will release the active antibacterial agent, via hydrolysis of the anomeric linkage, as illustrated in Scheme 1. Since different bacteria contain different glycosidase enzymes it is envisaged that selective inhibition can be effected by careful selection of the appropriate L-AEP glycoside. ${ }^{11}$ Importantly, glycosidases are much more specific and less widespread in the human body, particularly in the gut, than peptidases, and they have already proved invaluable for localized hydrolysis of prodrugs within a number of therapeutic strategies. ${ }^{13}$

Carbohydrate transporter
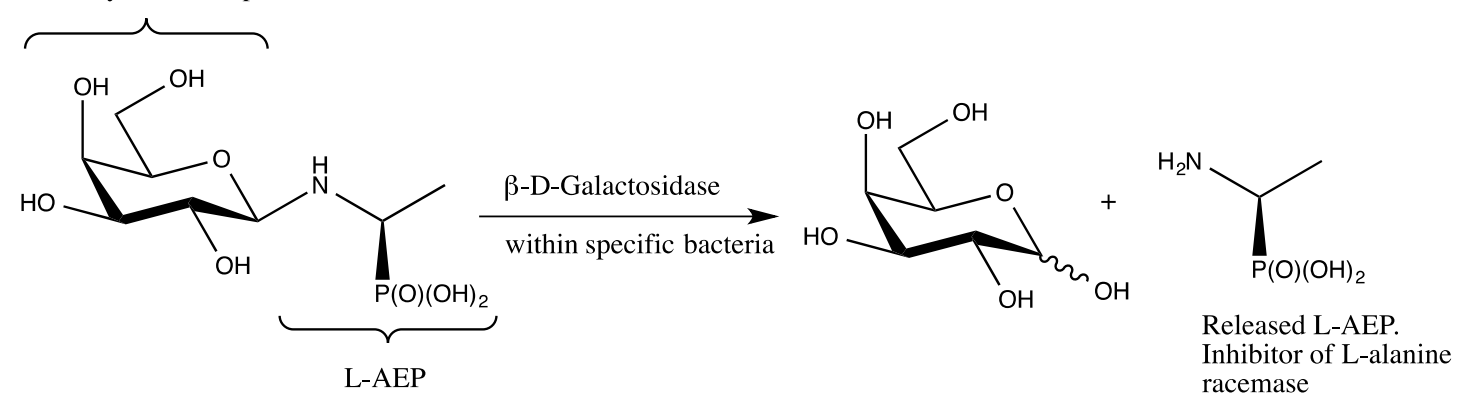

Scheme 1. Proposed Transport and Delivery Mechanism

The first four targets of interest, specifically the $N$-linked (1) and $O$-linked (2) glucosides and galactosides, required the direct attachment of L-AEP to glucose or galactose, as illustrated in Figure 1.

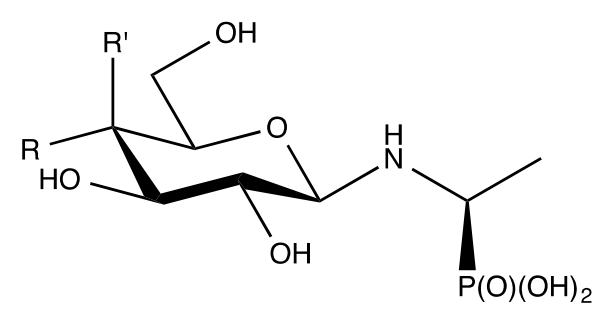

(1a) $\mathrm{R}=\mathrm{OH}, \mathrm{R}^{\prime}=\mathrm{H}$

(1b) $\mathrm{R}=\mathrm{H}, \mathrm{R}^{\prime}=\mathrm{OH}$

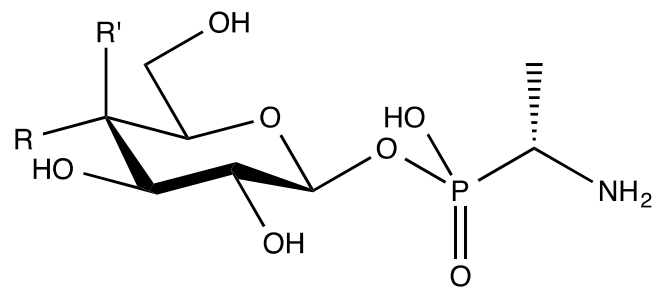

(2a) $\mathrm{R}=\mathrm{OH}, \mathrm{R}^{\prime}=\mathrm{H}$

(2b) $\mathrm{R}=\mathrm{H}, \mathrm{R}^{\prime}=\mathrm{OH}$

Figure 1. $\mathrm{N}$-Linked and $O$-linked glucoside and galactoside targets 
The $N$-linked derivative (1b) was accessed in 2 steps (Scheme 2), firstly by the reaction of LAEP (3) with 2,3,4,6-tetra- $O$-acetyl- $\alpha$-D-galactopyranoside bromide (4) to give the galactoside (5) which was purified by ion exchange column chromatography. This was then deprotected using Zémplen conditions to yield the $N$-linked derivative (1b) in 58\% overall yield. The successful formation of the $\beta$-anomer was evident from ${ }^{1} \mathrm{H}$ NMR spectroscopy, where a coupling constant of $10 \mathrm{~Hz}$ between $\mathrm{H} 1$ and $\mathrm{H} 2$ was consistent with an axial-axial arrangement of protons at C-1 and C-2. Synthesis of the glucose analogue (1a) was also attempted but as derivative (1a) proved to be extremely unstable, possibly due to a competing Amadori reaction, its synthesis was not investigated further.

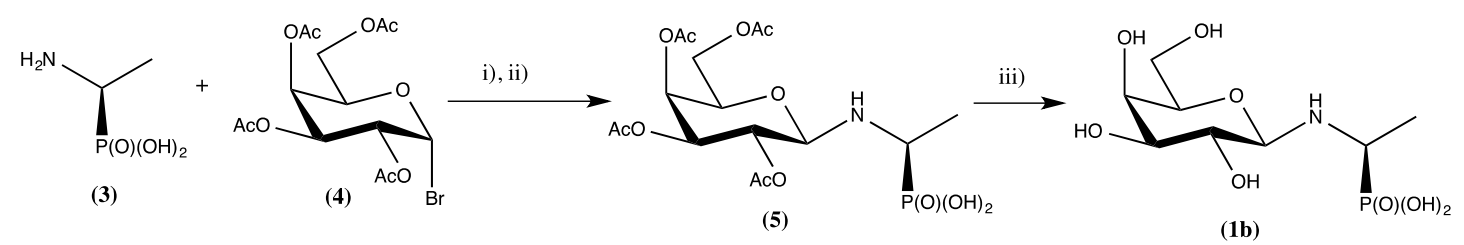

Scheme 2: Synthesis of $N$-linked galactoside (1b) i) $\mathrm{H}_{2} \mathrm{O}, \mathrm{Et}_{3} \mathrm{~N}$, rt. ii) DOWEX ion exchange column. iii) $\mathrm{NaOMe}, \mathrm{MeOH}, 30$ minutes, (1b) $58 \%$.

In order to synthesize the $O$-linked derivatives $(\mathbf{2 a})$ and $(\mathbf{2 b})$, the amine functionality of LAEP (3) was first protected as a benzoyl carbamate by reaction with benzyl chloroformate at $0{ }^{\circ} \mathrm{C}$ while keeping the $\mathrm{pH}$ at around 9.5 via addition of $\mathrm{NaOH}(4 \mathrm{M})$ as required. The Cbz- $\mathrm{L}-$ AEP (6) was then reacted with 2,3,4,6-tetra- $O$-benzyl- $\alpha$-D-glucopyranose trichloroacetimidate (7a) or 2,3,4,6-tetra- $O$ - $\alpha$-D-galactopyranose trichloroacetimidate (7b) to give the protected $O$-linked derivatives (8a) and (8b) (Scheme 3). These compounds were then de- $O$-benzylated via hydrogenation to give the $O$-linked targets (2a) in $89 \%$ yield and (2b) in $92 \%$ yield. 


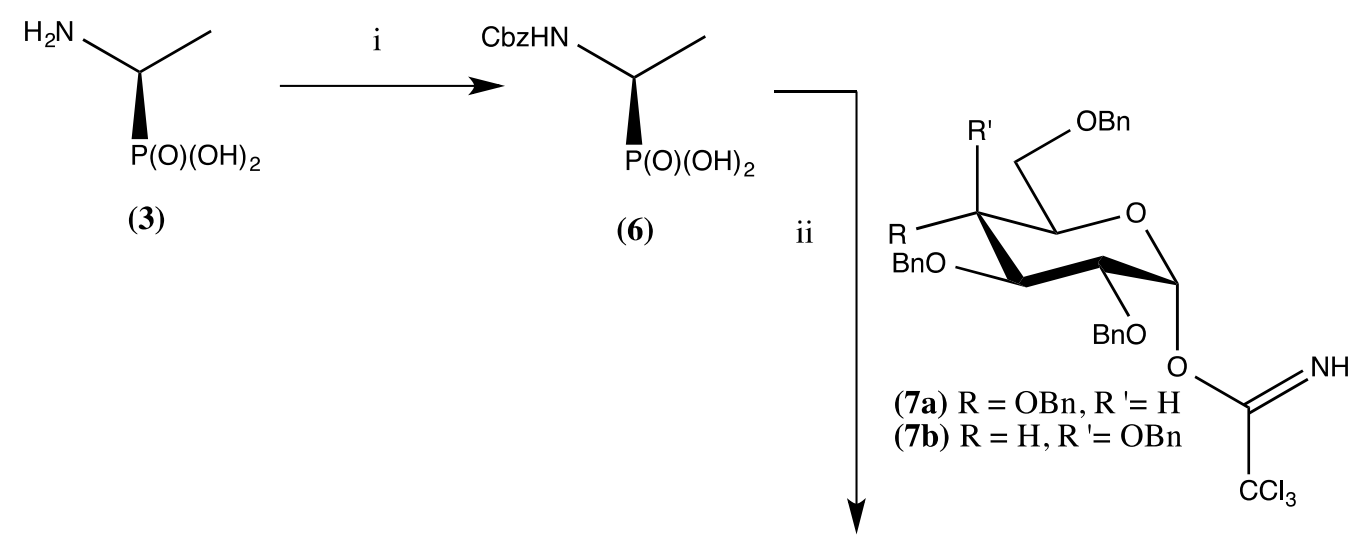

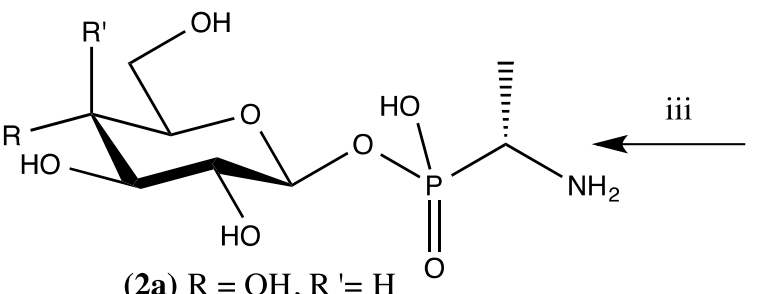

(2b) $\mathrm{R}=\mathrm{H}, \mathrm{R}^{\prime}=\mathrm{OH}$

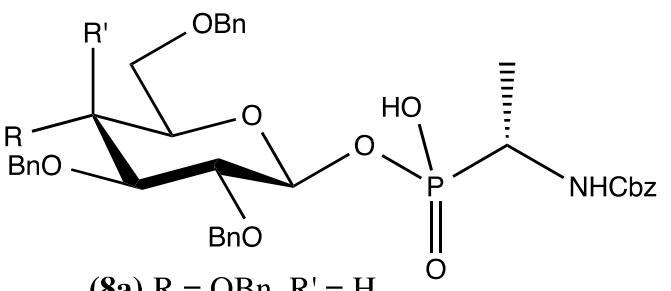

(8a) $\mathrm{R}=\mathrm{OBn}, \mathrm{R}^{\prime}=\mathrm{H}$

(8b) $\mathrm{R}=\mathrm{H}, \mathrm{R}{ }^{\prime}=\mathrm{OBn}$

Scheme 3: Synthesis of $O$-linked glucoside and galactoside (2a) and (2b) respectively i) $\mathrm{H}_{2} \mathrm{O}$, $\mathrm{NaOH}, \mathrm{Et}_{2} \mathrm{O}$, benzyl chloroformate, $0{ }^{\circ} \mathrm{C}, \mathrm{pH} \sim 9$. ii) $\mathrm{Et}_{2} \mathrm{O}, 3 \AA$ molecular sieves. iii) $\mathrm{EtOH}$, $\mathrm{H}_{2} \mathrm{O}, \mathrm{H}_{2}, \mathrm{Pd} / \mathrm{C}$, (2a) $89 \%$, (2b) $92 \%$.

The third targets of interest contained L-AEP linked to the sugar via a carbamate moiety (12a, 12b). It was hypothesized that such products would be more stable than the $N$-linked derivatives (1) but still able to release L-AEP upon hydrolysis. Thus carbamate linkages have previously been used within glycosidase labile prodrugs ${ }^{14}$ for example within a range of delivery systems, for example for cancer. ${ }^{15}$ In order to access the carbamate derivatives (12a and 12b) as $\beta$-linked glycosides, optimization of methodology was required. ${ }^{16}$ By varying the reaction conditions, as outlined in Table 1, the use of hydroxy benzotriazole and 4nitrobenzoylchloroformate with either the glucose $(\mathbf{9 a})$ or galactose derivative $(\mathbf{9 b})$ in the presence of a participating solvent proved optimum for affording the pure $\beta$-4-nitrobenzyl carbonate intermediates (10a and 10b) in good yield (Table 1, Scheme 4). 
The carbonates were then reacted with L-diethyl aminoethylphosphonate in the presence of Hunig's base and HOBt to give the pure $\beta$-carbamate linked products (11a) and (11b) in good yield. Deprotection of the diethyl phosphonate to afford the final targets (12a) and (12b) was conveniently combined with removal of the acetate groups by using $33 \%$ ammonia solution after addition of methanol.

Table 1. Preparation of $\beta$-4-nitrobenzyl carbonate glycoside

\begin{tabular}{cll}
\hline Experiment & \multicolumn{1}{c}{ Conditions } & \multicolumn{1}{c}{ Outcome } \\
\hline 1 & $\mathrm{Et}_{3} \mathrm{~N}, \mathrm{DCM}, \mathrm{rt}, 17 \mathrm{~h}$ & Mixture of anomers 1:1 \\
2 & $\mathrm{Et}_{3} \mathrm{~N}, \mathrm{DCM}, 0^{\circ} \mathrm{C}, 1.5 \mathrm{~h}$ & Mixture $\alpha: \beta 1: 2$ \\
3 & $\mathrm{DABCO}, \mathrm{DCM}, \mathrm{DMAP}, 0^{\circ} \mathrm{C}, 2 \mathrm{~h}$ & Mixture $\alpha: \beta 2: 1$ \\
4 & DABCO, THF, DMAP, $0^{\circ} \mathrm{C}, 2 \mathrm{~h}$ & Mixture $\alpha: \beta 1: 0.8$ \\
5 & DABCO, THF, HOBt, $0^{\circ} \mathrm{C}, 2 \mathrm{~h}$ & $\beta$-anomer only \\
\hline
\end{tabular}

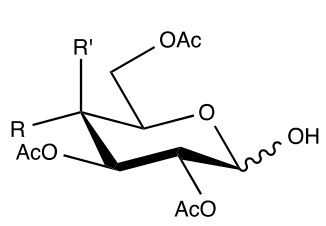

(9a) $\mathrm{R}=\mathrm{OAc}, \mathrm{R} '=\mathrm{H}$ (9b) $\mathrm{R}=\mathrm{H}, \mathrm{R}^{\prime}=\mathrm{OAc}$

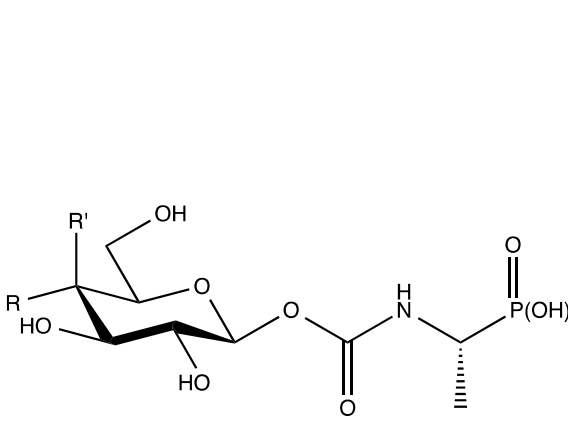

(12a) $\mathrm{R}=\mathrm{OH}, \mathrm{R}^{\prime}=\mathrm{H}$ (12b) $\mathrm{R}=\mathrm{H}, \mathrm{R}^{\prime}=\mathrm{OH}$

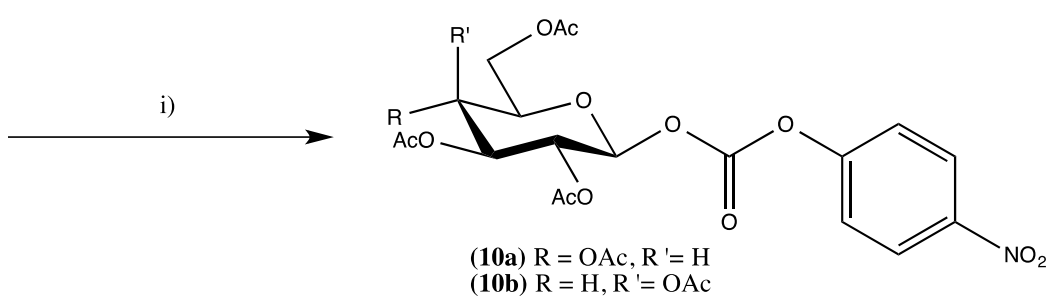

ii)<smiles>CCO[P+](=O)[C@@H](C)N</smiles><smiles>CCC</smiles>

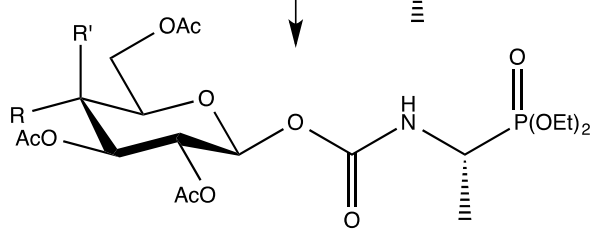

(11a) $R=$ OAc, $R^{\prime}=H$

Scheme 4: Synthesis of carbamate glycosides (12a) and (12b) i) $p-\mathrm{NO}_{2} \mathrm{C}_{6} \mathrm{H}_{4} \mathrm{OCOCl}$, DABCO, HOBt, THF, $0^{\circ} \mathrm{C}, 2 \mathrm{~h},(\mathbf{1 0 a}) 45 \%$, (10b) 68\% ii) DIPEA, HOBt, THF, 16h, (11a) 80\%, (11b) 59\% iii) TMSBr, DCM, 20h then $\mathrm{NH}_{4} \mathrm{OH}, \mathrm{MeOH}, 3-4 \mathrm{~h}$ then DOWEX ionexchange chromatography (12a) 80\%, (12b) $91 \%$ 
In an extension to this strategy, urea linked derivatives were also prepared as outlined in Scheme 5. Initially the glucose-1- $\beta$-amine (13a) ${ }^{17}$ was converted to the isocyanate (14a) in a one pot biphasic reaction originally reported by Nowick for the synthesis of peptides ${ }^{18}$ and later employed by Ichikawa ${ }^{19}$ with carbohydrates. This was then used for entry to (15a) and (15b), and then (16a) and (16b) in a similar manner to that reported for entry to (12a) and (12b).

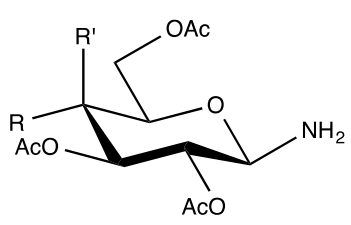

(13a) $\mathrm{R}=\mathrm{OAc}, \mathrm{R}^{\prime}=\mathrm{H}$ (13b) $\mathrm{R}=\mathrm{H}, \mathrm{R}^{\prime}=\mathrm{OAc}$<smiles>[2H]C1([2H])[C@@H](CO)O[C@H](NC(=O)N[C@@H](C)[Po](=O)O)[C@H](O)[C@H]1O</smiles>

(16a) $\mathrm{R}=\mathrm{OH}, \mathrm{R}^{\prime}=\mathrm{H}$ (16b) $\mathrm{R}=\mathrm{H}, \mathrm{R}^{\prime}=\mathrm{OH}$

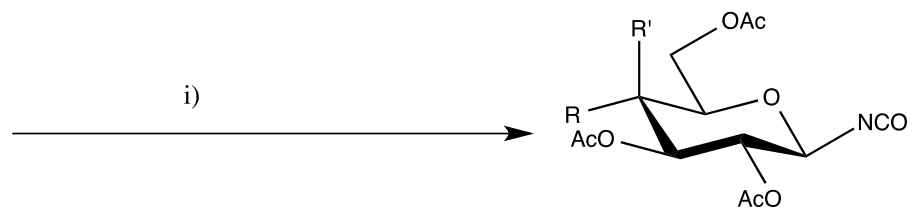

(14a) $\mathrm{R}=\mathrm{OAc}, \mathrm{R}^{\prime}=\mathrm{H}$ (14b) $R=H, R^{\prime}=O A c$

ii)<smiles>CCO[P+](=O)[C@H](C)N</smiles>

iii)

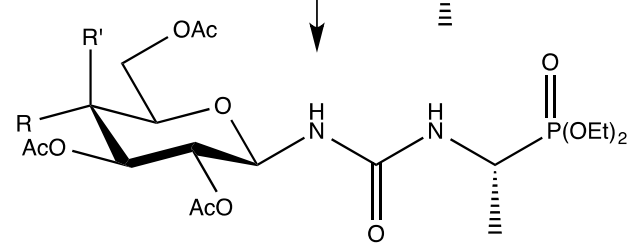

(15a) $\mathrm{R}=\mathrm{OAc}, \mathrm{R}^{\prime}=\mathrm{H}$ (15b) $\mathrm{R}=\mathrm{H}, \mathrm{R}^{\prime}=\mathrm{OAc}$

Scheme 5: Synthesis of urea glycosides (16a) and (16b) i) triphosgene, DCM, aq. $\mathrm{NaHCO}_{3}$, 30-45 min. ii) DCM, overnight, (15a) 60\% (15b) 21\% iii) TMSBr, DCM, 16h then $\mathrm{NH}_{4} \mathrm{OH}$, $\mathrm{MeOH}, 2-3 \mathrm{~h}$ then DOWEX ion-exchange chromatography (16a) 74\%, (16b) 70\%

For the final series of compounds two different spacer groups were incorporated between the carbohydrate and the AEP moiety. The extended spacer group concept has previously been used in conjunction with peptide carbohydrate conjugates. ${ }^{20}$ Access to the derivatives required synthesis of $(\mathbf{1 8 a})$ and $(\mathbf{1 8 b})^{21}$ with subsequent reaction of the alcohols with the isocyanate (17). The derivatives (19a) and (19b) were then deprotected under standard 
conditions and purified by ion-exchange chromatography to afford the aromatic carbamate linked AEP derivatives (20a) and (20b). For this series of compounds, epimeric mixtures resulted for (19a), (19b), (20a) and (20b), due to the use of a racemic AEP derivative when forming isocyanate (17).

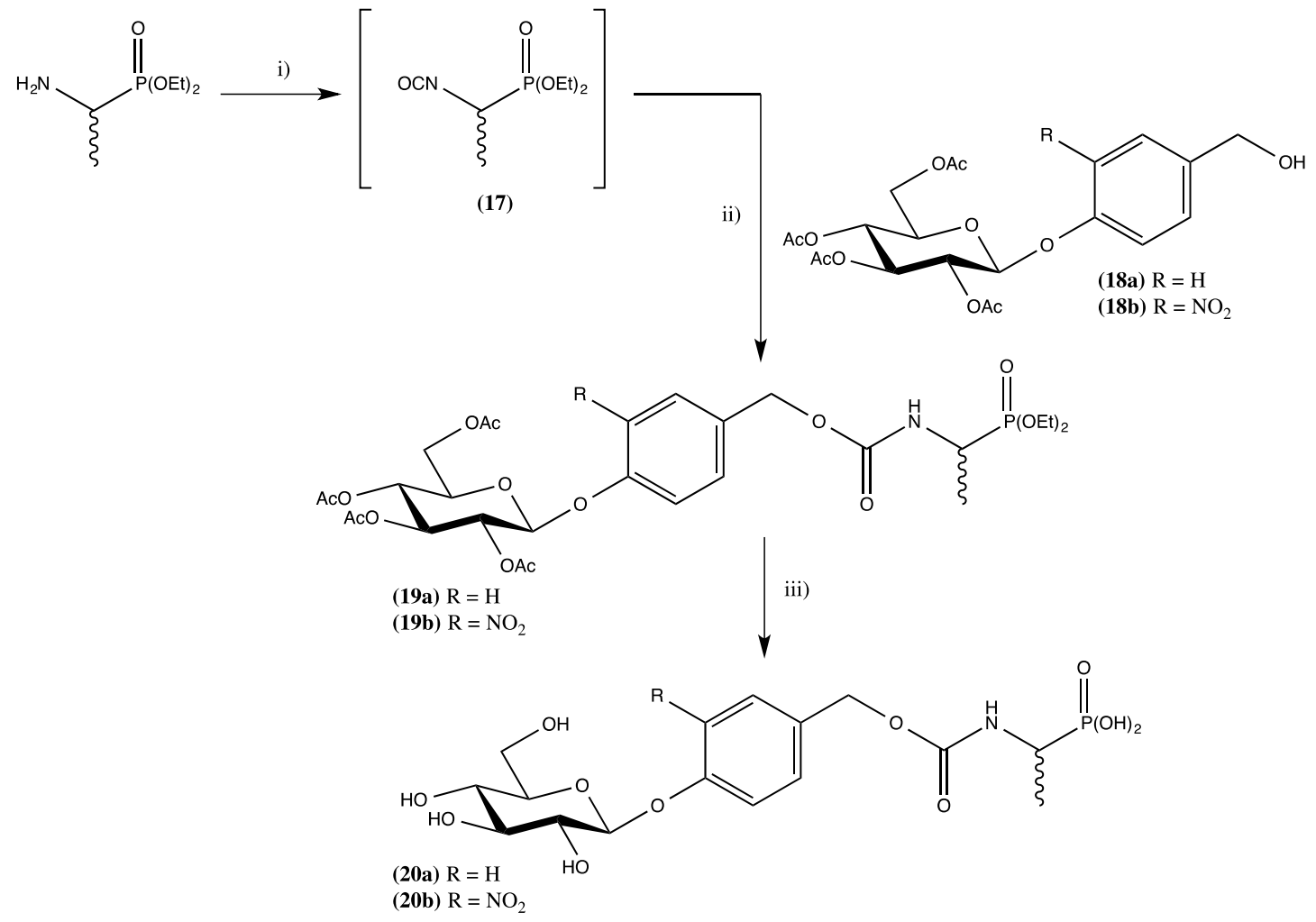

Scheme 6: Synthesis of extended carbamate glucosides (20a) and (20b) i) $\mathrm{Boc}_{2} \mathrm{O}$, DMAP, DCM or toluene, $0^{\circ} \mathrm{C}, 1 \mathrm{~h}$. ii) $\mathrm{Et}_{3} \mathrm{~N}$, overnight, iii) TMSBr, DCM, $16 \mathrm{~h}$ then $\mathrm{NH}_{4} \mathrm{OH}, \mathrm{MeOH}$, 3-4h then DOWEX ion-exchange chromatography, (20a) 35\% (20b) $40 \%$

The synthesized AEP-glycosides were then assessed to determine their ability to inhibit bacterial growth using a panel of Gram-negative bacteria. ${ }^{22}$ Growth of organisms was examined in 2 different types of media; a defined version (DM1; formulation based on that of Atherton et al. $^{23}$ ) containing amino acids rather than peptides, and a complex medium (Nutrient Broth Number 2, NB2; "Oxoid"; Thermofisher Scientific, Basingstoke, UK). Inhibitory activity was compared with hydrolysis of the equivalent chromogenic $o$ - 
nitrophenyl glycoside (ONP; $1 \mathrm{mg} / \mathrm{ml}$ in DM1 or NB2) to determine if the presence of the glycosidase hydrolyzing enzyme correlated with toxicity. Compound (1b) was too unstable to reliably bioassay. Compounds (2a) and (2b), (16a) and (16b), and (20a) and (20b) did not demonstrate any inhibitory activity in DM1 or NB2 even when added at a concentration of $1 \mathrm{mg} / \mathrm{ml}$. Pleasingly, carbamates (12a) and $(\mathbf{1 2 b})^{26}$ did inhibit the growth of a range of bacterial species, with lowest minimum inhibitory concentrations (MICs) being $<0.75 \mathrm{mg} / \mathrm{l}$. The inhibitory activity of glucoside (12a) was less at $\mathrm{pH} 7.2$ when organisms were tested in NB2 than in DM1 for the strains of C.sakazakii, Ps.aeruginosa and S.marcescens (Table 2). This mirrors the toxicity of AEP-peptides that are also reduced by complex media due to reduced uptake of the substrate by competitive inhibition. ${ }^{24}$ This would imply that the carbamate glucoside (12a) is also taken into the cell via the peptide permease systems rather than solely via glycoside transport mechanisms.

Table 2. MIC (mg/l) of (12a) (AEP-carbamate- $\beta$-D-glucoside) in different growth media and at $\mathrm{pH} 6.9$ and 7.2

\begin{tabular}{|c|c|c|c|c|c|}
\hline \multirow{2}{*}{$\begin{array}{c}\text { Colour } \\
\text { from } \\
\text { ONP- } \beta- \\
\text { Glu }\end{array}$} & \multirow{2}{*}{$\begin{array}{c}\text { Organisms } \\
\text { (ATCC numbers) }\end{array}$} & \multicolumn{2}{|c|}{ DM1 } & \multirow{2}{*}{$\begin{array}{c}\text { DM1 + } \\
\text { Glucose } \\
(0.5 \mathrm{~g} / \mathrm{l})\end{array}$} & \multirow{2}{*}{$\begin{array}{c}\text { NB2 } \\
\text { pH } 7.2\end{array}$} \\
\hline & & pH 6.9 & pH 7.2 & & \\
\hline+ & E.aerogenes 13048 & $<0.75$ & $>1.0$ & 1.0 & $>1.0$ \\
\hline+ & C.sakazakii 29544 & $<0.75$ & $<0.75$ & $<0.75$ & 1.0 \\
\hline- & K.pneumoniae 13882 & $>1.0$ & $>1.0$ & 1.0 & $>1.0$ \\
\hline- & P.mirabilis 14253 & $>1.0$ & $>1.0$ & $>1.0$ & $>1.0$ \\
\hline- & Ps.aeruginosa 27853 & $<0.75$ & $<0.75$ & 1.0 & 1.0 \\
\hline - & $\begin{array}{l}\text { S.enterica serovar } \\
\text { Typhimurium } 14028\end{array}$ & $>1.0$ & $>1.0$ & $>1.0$ & $>1.0$ \\
\hline - & $\begin{array}{l}\text { S.enterica serovar } \\
\text { Virchow } 5742 \\
\end{array}$ & $>1.0$ & $>1.0$ & $>1.0$ & $>1.0$ \\
\hline+ & S.marcescens 13880 & $<0.75$ & 1.0 & 1.0 & $>1.0$ \\
\hline
\end{tabular}

The addition of $0.5 \%$ glucose to DM1 at $\mathrm{pH} 7.2$ increased the toxicity of (12a) for E.aerogenes and K. pneumoniae but decreased it for Ps.aeruginosa. For the former, glucose may provide energy for active uptake into the cell. For the latter, glucose may repress uptake 
and hydrolysis by carbon catabolite repression. Decreasing the $\mathrm{pH}$ of DM1 from 7.2 to 6.9 increased the toxicity of (12a) for E. aerogenes and $S$. marcescens strains. An increased toxicity as $\mathrm{pH}$ decreases has also been observed for AEP-dipeptides. ${ }^{25}$ With the exception of the strain of Ps.aeruginosa, organisms that hydrolysed $o$-nitrophenyl- $\beta$-D-glucoside (ONP- $\beta$ Glu) were more susceptible to (12a) than those that did not, suggesting that release of free AEP by the glycosidase enzyme is required for toxicity, which is in line with our hypothesis.

Growth of 5 organisms was examined in the presence of $2 \mathrm{mg} / \mathrm{ml}$ of (12b) in DM1 without glucose, and with and without the gratuitous inducer iso-propyl- $\beta$-D-galactoside (IPTG) at $1 \mathrm{mg} / \mathrm{ml}$ (Table 3). Cronobacter sakazakii and K.pneumoniae grew without IPTG but were inhibited when it was added. Surprisingly, E.aerogenes hydrolysed o-nitrophenyl- $\beta$-Dgalactoside and it does, therefore, have mechanisms for uptake and hydrolysis of galactosides, but its growth was unaffected by galactoside (12b).

Table 3. Growth of organisms in the presence of $2 \mathrm{mg} / \mathrm{ml} 16 \mathrm{~b}$ in DM1 $\mathrm{pH} 7.2$ without glucose and with and without IPTG

\begin{tabular}{|l|c|c|c|}
\hline \multicolumn{1}{|c|}{ Organisms (ATCC numbers) } & $\begin{array}{c}\text { Growth } \\
\text { without IPTG }\end{array}$ & $\begin{array}{c}\text { Growth with } \\
\text { IPTG }\end{array}$ & $\begin{array}{c}\text { Colour from } \\
\text { ONP- } \beta \text {-Gal }\end{array}$ \\
\hline E.aerogenes 13048 & + & + & + \\
\hline C sakazakii 29544 & + & - & + \\
\hline K.pneumoniae 13882 & + & - & - \\
\hline S.enterica serovar Typhimurium 14028 & + & + & - \\
\hline S.enterica serovar Virchow 5742 & + & + & + \\
\hline
\end{tabular}

In summary, a series of ten AEP glycosides has been prepared. All were stable except the $N$ linked glycosides (1a) and (1b). The carbamate compounds (12a) and (12b) demonstrated inhibitory activity for the organisms that were examined with best MIC values of $<0.75 \mathrm{mg} / \mathrm{l}$ being observed for some bacterial species. Inhibition, in nearly all cases, was closely related to the hydrolysis of the equivalent chromogenic glycosides suggesting that release was 
mediated by the glycosidase enzyme. This is in line with the hypothesis that glycoside derivatives of antibacterial agents can facilitate selective, targeted delivery of antibacterial agents, via their in situ hydrolysis by bacterial borne glycosidase enzymes.

\section{Acknowledgements}

The authors are grateful to Thermofisher Scientific and the BBSRC (BB/E527812/1) for their financial support of this work.

\section{References and notes}

1. a) For example, see a) Freire-Moran, L.; Aronsson, B.; Manz, C.; Gyssens, I.C.; So, A.D.; Monnet, D.L.; Cars, O. Drug Resist. Update, 2011, 14, 118; b) Fedorenko, V.; Genilloud, O.;

Horbal, L.; Marcone, G.L.; Marinelli, F.; Paitan, Y.; Ron, E.Z. Biomed. Research International, 2015, 591349.

2. a) Alanis, A.J. Archive. Med. Res, 2005, 36, 697; b) Barrett, C.T.; Barrett, J.F. Curr. Opin. Biotech, 2003, 14, 621; c) Walsh, C. Nature, 2000, 406, 775; d) Wright, G.D. Chem. Bio, 2000, R127; e) Culyba, M.J.; Mo, C.Y.; Kohli, R.M. Biochem., 2015, 54, 3573.

3. a) Stamper, C.G.F.; Morollo, A.A.; Ringe, D. Biochem., 1998, 37, 10438; b) Hol, P.; Defrenne, C.; Ferain, T.; Derzelle, S.; Deplace, B.; Delcour, J. J. Bacteriology, 1997, 179, 3804; c) Fenn, T.D.; Holyoak, T.; Stamper, C.G.F.; Ringe, D. Biochem., 2005, 44, 531.

4. a) Conti, P.; Tamborini, L.; Pinto, A.; Blondel, A.; Minoprio, P.; Mozzarelli, A.; De Micheli, C. Chem. Rev., 2011, 11, 6919; b) Eliot, A.C.; Kirsch, J.F. Ann. Rev. Biochem., 2004, 73, 383; c) Amadasi, A.; Bertoldi, M.; Constestabil, R.; Bettati, S.; Cellini, B.; di Salvo, M.L.; Borri-Voltattorni, C.; Bossa, F.; Mozzarelli, A. Curr. Med. Chem., 2007, 14, 1291; d) Song, Y.; Niederer, D.; Lane-Bell, P.M.; Lam, L.K.P.; Crawley, S.; Palcic, M.M.; Pickard, M.A.; Pruess, D.L.; Vederas, J.C. J. Org. Chem., 1994, 59, 5784; e) Thornberry, N.A.; Bull, H.G.; Taub, D.; Wilson, K.E.; Gimenqz-Gallego, G.; Rosegay, A.; Soderman, D.D.; Pachett, 
A.A. J. Biol. Chem., 1991, 266, 21657.

5. Vo-Quang, V.; Carniato, D.; Vo-Quang, L.; Lacoste, A.M.; Neuzil, E.; Le Goffic, F. J. Med. Chem., 1986, 29, 148.

6. a) Stamper, C.G.F.; Morollo, A.A.; Ringe, D. Biochem., 1998, 37, 10438; b) Badet, B.; Inagaki, K.; Soda, K.; Walsh, C.T. Biochem., 1986, 25, 3275; c) Badet, B.; Walsh, C.T. Biochem., 1985, 24, 1333.

7. a) Allen, J.G.; Atherton, F.R.; Hall, M.J.; Hassall, C.H.; Holmes, S.W.; Lambert, R.W.; Nisbet, L.J.; Ringrose, P.S. Antimicrob. Agents and Chemotherapy, 1979, 15, 684; b) Atherton, F.R.; Hall, M.J.; Hassall, C.H.; Lambert, R.W.; Ringrose P.S. Antimicrob. Agents and Chemotherapy, 1979, 19, 677; c) Kafarski, P.; Lejczak, B. Curr. Med. Chem., 2001, 1, 301.

8. Perry, J.D.; Riley, G.; Gould, F.K.; Perez, J.M.; Boissier, E.; Ouedraogo, R.T.; Freydiere, A.M. J. Clin. Microbiol., 2002, 40, 3913.

9 a) Neuman, M. J. Antimicrob. Chemother., 1984, 14, 309; b) Chopra, I. J. Appli. Bacteriol., 1988, 65, S149; c) Barak, Z. J. Biol. Chem., 1974, 249, 143.

10. a) Milner, S.J.; Carrick, C.T.; Kerr, K.G.; Snelling, A.M.; Thomas, G.H.; Duhme-Klair, A.K.; Routledge, A. Chembiochem., 2014, 15, 466; b) Jung, M.E.; Yang, E.C.; Vu, B.T.; Kiankarimi, M.; Spyrou, E.; Kaunitz, J. J. Med. Chem., 1999, 42, 3899; c) Conners, S.B. J. Bacteriol., 2005, 187, 7267; d) Barrangou, R. Proc. Natl. Acad. Sci., 2006, 103, 3816.

11. a) Cellier, M.; Fazackerley, E.; James, A.L.; Orenga, S.; Perry, J.D.; Turnbull, G.; Stanforth, S.P. Bioorg. Med. Chem., 2014, 22, 1250; b) Orenga, S.; James, A.L.; Manafi, M.; Perry, J.D.; Pincus, D.H. J. Microbiol. Methods, 2009, 79, 139; c) Perry, J.D.; Morris, K.A.; James A.L.; Oliver, M.; Gould, F.K. J. Appl. Microbiol., 2007, 102, 410; d) Chilvers, K.F.; Perry, J.D.; James, A.L.; Reed, R.H. J. Appl. Microbiol., 2001, 91, 1118.

12. Fernandez, C.; Nieto, O.; Fontenla, J.A.; Rivas, R.; de Ceballos, M.L.; FernandezMayoralas, A. Org. Biom. Chem., 2003, 1, 767.

13. a) Reynolds, R.C.; Tiwari, A.; Harwell, J.E.; Gordon, D.G.; Garrett, B.D.; Gilbert, K.S. ; Schmid, S.M.; Waud, W.R.; Struck, R.F. J. Med. Chem., 2000, 43, 1484; b) Leenders, 
R.G.G.; Damen, E.W.P.; Bijsterveld, E.J.P.; Scheeren, H.W.; Houba, P.H.J.; van der MeulenMuileman, I.H.; Boven, E.; Haisma, H.J. Bioorg. Med. Chem., 1999, 7, 1597.

14. Leender, R.G.G.; Ruytenbeck, R.; Damen, E.W.P.; Scheeren, H.W. Synthesis, 1996, 1309.

15. a) Reynolds, R.C.; Tiwari, A.; Harwell, J.E.; Gordon, D.G.; Garrett, B.D.; Gilbert, K.S.; Schmid, S.M.; Waud, W.R.; Struck, R.F. J. Med. Chem., 2000, 43, 1484; b) Leenders, R.G.G.; Damen, E.W.P.; Bijsterveld, E.J.P.; Scheeren, H.W.; Houba, P.H.J.; van der MeulenMuileman, I.H.; Boven, E.; Haisma, H.J. Bioorg. Med. Chem., 1999, 7, 1597.

16. a) Knölker, H-J.; Braxmeier, T. Synlett, 1997, 925; b) Waldmann, H.; Kappes, T. Carbohydr. Res., 1998, 305, 341; c) Gum, A.G.; Kappes-Roth, T.; Waldmann, H. Chem. Eur. J., 2000, 6, 3714 .

17. Shiozaki, M.; Mochizuki, T.; Hanzawa, H.; Haruyama, H. Carbohydr. Res., 1996, 288, 99.

18. Nowick, J.S.; Holmes, D.L.; Noronha, G.; Smith, E.M.; Nguyen, T.M.; Huang, S-L. J. Org. Chem., 1996, 3929.

19. Ichikawa, Y.; Nishiyama, T.; Isobe, M. J. Org. Chem., 2001, 66, 4200.

20. Kadereit, D.; Waldmann, H. Chem. Rev., 2001, 101, 3367.

21. a) Leu, Y-L.; Roffler, S.R.; Cherm, J-W. J. Med. Chem., 1999, 42, 11, 3623; b) Florent, JC.; Dong, X.; Gaudel, G.; Mitaku, S.; Monneret, C.; Gesson, J-P.; Jacquesy, J-C.; Mondon, M.; Renoux, B.; Andrianomenjanahary, S.; Michel, S.; Koch, M.; Tillequin, F.; Gerken, M.; Czech, J.; Straub, R.; Bosslet, K. J. Med. Chem., 1998, 41, 19, 3572. c) Bouvier, E.; Thirot, S.; Schmidt, F.; Monneret, C. Org. Biomol. Chem., 2003, 1, 19, 3343.

22. Biological screening was carried out using a Bioscreen. To the Bioscreen plate wells defined media $(300 \mu \mathrm{l})$ was added followed by a 1 in 10000 dilution of cultures $(30 \mu \mathrm{l})$. All cultures were grown overnight at $37{ }^{\circ} \mathrm{C}$ in Nutrient Broth before dilution in maximum recovery diluent. Plates were then incubated at $37{ }^{\circ} \mathrm{C}$, with shaking for 10 seconds before each measurement and optical density measurements taken at $603 \mathrm{~nm}$ at intervals over approximately 24 hours. 
23. Atherton, F.R.; Hall, M.J.; Hassall, C.H.; Holmes, S.W.; Lambert, R.W.; Lloyd, W.J.; Ringrose P.S., Antimicrob. Agents Chemother., 1980, 18, 897.

24. Atherton, F.R.; Hall, M.J.; Hassall, C.H.; Lambert, R.W.; Lloyd, W.J.; Lord, A.V.; Ringrose, P.S.; Westmacott, D. Antimicrob. Agents Chemother., 1983, 24, 522.

25. R. Bovill unpublished data.

26. a) To 2,3,4,6-tetra- $O$-acetyl-D-glucose (9a) $(6.82 \mathrm{~g}, 19.6 \mathrm{mmol})$ in dry THF (70 ml) cooled to $0^{\circ} \mathrm{C}$ under argon, was added 1,4-diazabicyclo(2.2.2)octane $(3.55 \mathrm{~g}, 31.6 \mathrm{mmol})$ and the solution was stirred for 2 minutes before the addition of 1-hydroxybenzotriazole hydrate $(0.55 \mathrm{~g}, 4.1 \mathrm{mmol})$ followed by 4-nitrophenyl chloroformate (4.78 g, $23.7 \mathrm{mmol})$. The mixture was stirred for 2 hours at $0^{\circ} \mathrm{C}$ and then filtered through a short pad of silica eluting with hexane-EtOAc $(1: 1)$ to remove the white $\mathrm{HCl}$ salt precipitate formed. The product was purified by flash column chromatography on silica eluting with hexane-EtOAc (3:2), to yield the pure $\beta$-glucoside (10a) (4.56 g, 45\%) as a cream solid (Rf 0.47 hexane-EtOAc 1:1). m.p. $135-136^{\circ} \mathrm{C} \mathrm{dec} ;[\alpha]^{20}{ }_{\mathrm{D}}-3.6^{\circ}\left(c 1, \mathrm{CHCl}_{3}\right) ;{ }^{1} \mathrm{H}$ NMR $\left(250 \mathrm{MHz}, \mathrm{CDCl}_{3}\right) \delta: 8.30(2 \mathrm{H}, \mathrm{d}, J=9.0$ $\mathrm{Hz}, \mathrm{ArH}), 7.44(2 \mathrm{H}, \mathrm{d}, J=9.0 \mathrm{~Hz}, \mathrm{ArH}), 5.70(1 \mathrm{H}, \mathrm{d}, J=7.5 \mathrm{~Hz}, \mathrm{H}-1), 5.35-5.16(3 \mathrm{H}, \mathrm{m}, \mathrm{H}-$ 2,3 and H-4), 4.34 (1H, dd, $J=4.5,12.5 \mathrm{~Hz}, \mathrm{H}-6 \mathrm{a}), 4.18$ (1H, dd, $J=2.0,12.5 \mathrm{~Hz}, \mathrm{H}-6 \mathrm{~b})$, $3.94(1 \mathrm{H}, \mathrm{ddd}, J=2.0,4.5,9.5 \mathrm{~Hz}, \mathrm{H}-5), 2.10$ (3H, s, Ac), 2.10 (3H, s, Ac), 2.05 (3H, s, Ac),

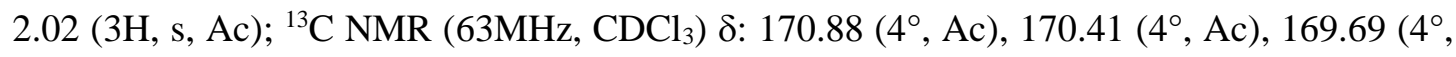

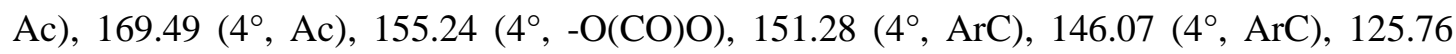
(ArC), 122.01 (ArC), $96.24(\mathrm{C}-1), 73.28(\mathrm{C}-5), 72.81(\mathrm{CH}), 70.37(\mathrm{CH}), 67.79(\mathrm{CH}), 61.64$ (C-6), $21.03\left(\mathrm{CH}_{3}, \mathrm{Ac}\right), 20.96\left(\mathrm{CH}_{3}, \mathrm{Ac}\right), 20.89\left(\mathrm{CH}_{3}, \mathrm{Ac}\right), 20.89\left(\mathrm{CH}_{3}, \mathrm{Ac}\right)$.

b) To 2,3,4,6-tetra- $O$-acetyl-D-galactose (9b) $(8.32 \mathrm{~g}, 24 \mathrm{mmol})$ in dry THF ( $80 \mathrm{ml})$ cooled to $0{ }^{\circ} \mathrm{C}$ under argon, was added 1,4-diazabicyclo(2.2.2)octane (4.08 g, $\left.36.4 \mathrm{mmol}\right)$ and the solution was stirred for 2 minutes before the addition of 1-hydroxybenzotriazole hydrate $(0.65$ $\mathrm{g}, 4.8 \mathrm{mmol})$ followed by 4-nitrophenyl chloroformate $(5.84 \mathrm{~g}, 28.9 \mathrm{mmol})$. The mixture was stirred for 2 hours at $0^{\circ} \mathrm{C}$ and then filtered through a short pad of silica eluting with hexaneEtOAc $(1: 1)$ to remove the white $\mathrm{HCl}$ salt precipitate formed. The product was purified by flash column chromatography on silica eluting with hexane-EtOAc (3:2 then 1:1) to yield the pure $\beta$-galactoside (10b) (8.35 g, 68\%) as a cream solid (Rf 0.50 hexane-EtOAc 1:1) m.p. 59$62^{\circ} \mathrm{C} .[\alpha]^{20} \mathrm{D}+10.5^{\circ}\left(c 1, \mathrm{CHCl}_{3}\right) ;{ }^{1} \mathrm{H}$ NMR $\left(250 \mathrm{MHz}, \mathrm{CDCl}_{3}\right) \delta: 8.30(2 \mathrm{H}, \mathrm{d}, J=9.5 \mathrm{~Hz}$, ArH), $7.42(2 \mathrm{H}, \mathrm{d}, J=9.5 \mathrm{~Hz}, \mathrm{ArH}), 5.66(1 \mathrm{H}, \mathrm{d}, J=8.0 \mathrm{~Hz}, \mathrm{H}-1), 5.47-5.43$ (2H, overlapped m, H-2 and H-4), 5.17-5.11 (1H, dd, $J=8.0,1.5$ Hz, H-3), 4.22-4.05 (3H, m, H-6 and H-5), $2.19(3 \mathrm{H}, \mathrm{s}, \mathrm{Ac}), 2.11(3 \mathrm{H}, \mathrm{s}, \mathrm{Ac}), 2.05(3 \mathrm{H}, \mathrm{s}, \mathrm{Ac}), 2.02(3 \mathrm{H}, \mathrm{s}, \mathrm{Ac}) ;{ }^{13} \mathrm{C}$ NMR $(63 \mathrm{MHz}$,

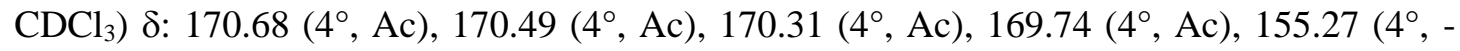

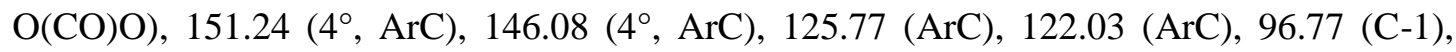


72.30 (C-5), 70.93 (C-3), $68.19(\mathrm{CH}), 66.94(\mathrm{CH}), 61.31(\mathrm{C}-6), 21.16\left(\mathrm{CH}_{3}, \mathrm{Ac}\right), 21.06\left(\mathrm{CH}_{3}\right.$, Ac), $20.99\left(\mathrm{CH}_{3}, \mathrm{Ac}\right), 20.86\left(\mathrm{CH}_{3}, \mathrm{Ac}\right)$.

c) To $\beta$-glucoside (10a) $(3.94 \mathrm{~g}, 7.7 \mathrm{mmol})$ in anhydrous THF $(60 \mathrm{ml})$ with $(R)$ aminodiethylphosphonate $(1.83 \mathrm{~g}, 10.1 \mathrm{mmol})$ and 1-hydroxy benzotriazole hydrate $(1.040 \mathrm{~g}$, $7.7 \mathrm{mmol})$ under argon was added $3 \AA$ molecular sieves $(5.7 \mathrm{~g})$ followed by $N, N^{\prime}$ diisopropylethylamine $(2.0 \mathrm{ml}, 11.4 \mathrm{mmol})$ whereupon the solution turned yellow. After stirring at room temperature for $16 \mathrm{~h}$ the mixture was filtered through a short pad of silica eluting with ethyl acetate. The nitrophenol byproduct (Rf 0.63 EtOAc) was removed by extracting the product in DCM followed by washing of the organic layer by $1 \mathrm{M} \mathrm{NaOH}$ until the aqueous layer was no longer yellow. The DCM layer was dried $\left(\mathrm{MgSO}_{4}\right)$, filtered and the solvent removed in vacuo. The product was purified by flash column chromatography on silica eluting with hexane-EtOAc (1:4) then EtOAc to give $\beta$-glucoside (11a) $(3.41 \mathrm{~g}, 80 \%)$ as a white solid (Rf 0.39 EtOAc). m.p. $\left.154-155^{\circ} \mathrm{C} .[\alpha]^{20}{ }_{\mathrm{D}}-8.2^{\circ}(c) 1, \mathrm{CHCl}_{3}\right) ;{ }^{1} \mathrm{H}$ NMR $\left(250 \mathrm{MHz}, \mathrm{CDCl}_{3}\right) \delta: 5.67(1 \mathrm{H}, \mathrm{d}, J=8.5 \mathrm{~Hz}, \mathrm{H}-1), 5.39(1 \mathrm{H}, \mathrm{br}, \mathrm{d}, J=10.0 \mathrm{~Hz}, \mathrm{NH}), 5.22$ (1H, app. t, $J=9.5 \mathrm{~Hz}, \mathrm{H}-3), 5.19-5.07(2 \mathrm{H}, \mathrm{m}, \mathrm{H}-4$ and H-2), $4.31(1 \mathrm{H}, \mathrm{dd}, J=4.5,12.5 \mathrm{~Hz}$, H-6a), 4.19-4.01 (6H, m, H-6b, CH of AEP, 2 x OC$\left.\underline{H}_{2} \mathrm{CH}_{3}\right), 3.84$ (1H, ddd, $J=2.0,4.5,10.0$ Hz, H-5), 2.08 (3H, s, Ac), 2.03 (3H, s, Ac), 2.03 (3H, s, Ac), 2.02 (3H, s, Ac), 1.40 (3H, dd, $J=7.5,16.5 \mathrm{~Hz}, \mathrm{CH}_{3}$ of AEP), $1.34\left(3 \mathrm{H}, \mathrm{t}, J=7.0 \mathrm{~Hz}, \mathrm{OCH}_{2} \mathrm{C}_{3}\right), 1.30(3 \mathrm{H}, \mathrm{t}, J=7.0 \mathrm{~Hz}$,

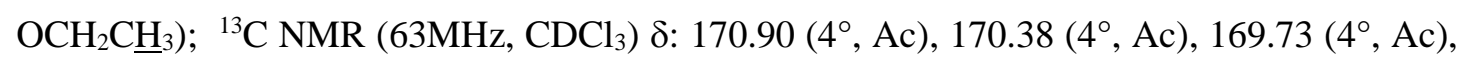
$169.56\left(4^{\circ}, \mathrm{Ac}\right), 153.58\left(4^{\circ},-\mathrm{O}(\mathrm{CO}) \mathrm{NH}\right), 93.32(\mathrm{C}-1), 73.08$ (C-3), $72.83(\mathrm{C}-5), 70.49(\mathrm{C}-\mathrm{H})$, $68.08(\mathrm{C}-\mathrm{H}), 63.03\left(\mathrm{~d}, J_{\mathrm{C}, \mathrm{P}}=4 \mathrm{~Hz}, \mathrm{OCH}_{2} \mathrm{CH}_{3}\right), 62.93\left(\mathrm{~d}, J_{\mathrm{C}, \mathrm{P}}=4 \mathrm{~Hz}, \mathrm{OCH}_{2} \mathrm{CH}_{3}\right), 61.75(\mathrm{C}-$ 6), $43.72\left(\mathrm{~d}, J_{\mathrm{C}, \mathrm{P}}=159 \mathrm{~Hz}, \mathrm{CH}\right.$ of AEP), $21.00\left(\mathrm{CH}_{3}, \mathrm{Ac}\right), 20.87\left(\mathrm{CH}_{3}, \mathrm{Ac}\right), 20.87\left(\mathrm{CH}_{3}, \mathrm{Ac}\right)$, $20.79\left(\mathrm{CH}_{3}, \mathrm{Ac}\right), 16.79\left(\mathrm{OCH}_{2} \mathrm{CH}_{3}\right), 16.70\left(\mathrm{OCH}_{2} \underline{\mathrm{CH}}_{3}\right), 15.89\left(\mathrm{CH}_{3}\right.$ of $\left.\mathrm{AEP}\right)$.

d) To $\beta$-galactoside (10b) $(7.87 \mathrm{~g}, 15.3 \mathrm{mmol})$ in anhydrous THF $(110 \mathrm{ml})$ with $(R)$ aminodiethylphosphonate $(3.33 \mathrm{~g}, 18.3 \mathrm{mmol})$ and 1-hydroxy benzotriazole hydrate $(2.07 \mathrm{~g}$, $15.3 \mathrm{mmol})$ under argon was added $3 \AA$ molecular sieves $(8.8 \mathrm{~g})$ followed by $N, N^{\prime}$ diisopropylethylamine $(4.0 \mathrm{ml}, 22.9 \mathrm{mmol})$ whereupon the solution turned yellow. After stirring at room temperature for $16 \mathrm{~h}$ the mixture was filtered through a short pad of silica eluting with ethyl acetate. The nitrophenol byproduct ( $\mathrm{Rf} 0.63$ EtOAc) was removed by extracting the product in DCM followed by washing of the organic layer by $1 \mathrm{M} \mathrm{NaOH}$ until the aqueous layer was no longer yellow. The DCM layer was dried $\left(\mathrm{MgSO}_{4}\right)$, filtered and the solvent removed in vacuo. The product was purified by flash column chromatography on silica eluting with hexane-EtOAc (1:4) then EtOAc to give $\beta$-galactoside (11b) $(5.00 \mathrm{~g}, 59 \%)$ as a white solid (Rf 0.34 EtOAc). M.p. $129-132^{\circ} \mathrm{C} ;[\alpha]^{20}{ }_{\mathrm{D}}+14.6^{\circ}\left(c \quad 1, \mathrm{CHCl}_{3}\right) ;{ }^{1} \mathrm{H} \mathrm{NMR}$ $\left(250 \mathrm{MHz}, \mathrm{CDCl}_{3}\right) \delta: 5.66(1 \mathrm{H}, \mathrm{d}, J=8.5 \mathrm{~Hz}, \mathrm{H}-1), 5.48(1 \mathrm{H}, \mathrm{br}, \mathrm{d}, J=9.5 \mathrm{~Hz}, \mathrm{NH}), 5.42$ $(1 \mathrm{H}, \mathrm{d}, J=3.5 \mathrm{~Hz}, \mathrm{H}-4), 5.34-5.25(1 \mathrm{H}, \mathrm{m}, \mathrm{H}-2), 5.10(1 \mathrm{H}, \mathrm{dd}, J=3.5,10.5 \mathrm{~Hz}, \mathrm{H}-3), 4.19-$ 
$4.05\left(8 \mathrm{H}, \mathrm{m}, \mathrm{H}-5, \mathrm{H}-6,2 \times \mathrm{OC}_{2} \mathrm{CH}_{3}\right.$ and $\mathrm{CH}$ of $\left.\mathrm{AEP}\right), 2.16$ (3H, s, Ac), $2.04(6 \mathrm{H}, \mathrm{s}, 2 \mathrm{xAc})$, $1.99(3 \mathrm{H}, \mathrm{s}, \mathrm{Ac}), 1.30\left(3 \mathrm{H}, \mathrm{dd}, J=10.5,16.5 \mathrm{~Hz}, \mathrm{CH}_{3}\right.$ of AEP), $1.32(3 \mathrm{H}, \mathrm{t}, J=7.0 \mathrm{~Hz}$, $\left.\mathrm{OCH}_{2} \underline{\mathrm{H}}_{3}\right), 1.28\left(3 \mathrm{H}, \mathrm{t}, J=7.0 \mathrm{~Hz}, \mathrm{OCH}_{2} \mathrm{C}_{3}\right) ;{ }^{13} \mathrm{C} \mathrm{NMR}\left(63 \mathrm{MHz}, \mathrm{CDCl}_{3}\right) \delta: 170.63\left(4^{\circ}\right.$, Ac), 170.26 ( $\left.4^{\circ}, \mathrm{Ac}\right), 170.15\left(4^{\circ}, \mathrm{Ac}\right), 169.71\left(4^{\circ}, \mathrm{Ac}\right), 153.65\left(4^{\circ},-\mathrm{O}(\mathrm{CO}) \mathrm{NH}\right), 93.79(\mathrm{C}-1)$, 71.76 (C-5), 71.13 (C-3), 68.08 (C-2), 67.17 (C-4), 62.98 (d, $J_{\mathrm{C}, \mathrm{P}}=4 \mathrm{~Hz}, \mathrm{OCH}_{2} \mathrm{CH}_{3}$ ), 62.86 $\left(\mathrm{d}, J_{\mathrm{C}, \mathrm{P}}=4 \mathrm{~Hz}, \mathrm{OCH}_{2} \mathrm{CH}_{3}\right), 61.53(\mathrm{C}-6), 45.26\left(\mathrm{~d}, J_{\mathrm{C}, \mathrm{P}}=158 \mathrm{~Hz}, \mathrm{CH}\right.$ of AEP), $21.02\left(\mathrm{CH}_{3}\right.$, Ac), $20.92\left(\mathrm{CH}_{3}, \mathrm{Ac}\right), 20.85\left(\mathrm{CH}_{3}, \mathrm{Ac}\right), 20.85\left(\mathrm{CH}_{3}, \mathrm{Ac}\right), 16.79\left(\mathrm{OCH}_{2} \mathrm{CH}_{3}\right), 16.70$ $\left(\mathrm{OCH}_{2} \underline{\mathrm{C}} \mathrm{H}_{3}\right), 15.95\left(\mathrm{CH}_{3}\right.$ of AEP).

e) To the $\beta$-glucoside (11a) $(2.71 \mathrm{~g}, 4.8 \mathrm{mmol})$ in anhydrous dichloromethane $(50 \mathrm{ml})$ was added trimethylsilylbromide $(2.5 \mathrm{ml}, 19.5 \mathrm{mmol})$ and the solution was stirred overnight $(20 \mathrm{~h})$ at room temperature. Methanol $(20 \mathrm{ml})$ was added and the mixture stirred for 15 minutes after which time aq. ammonium hydroxide $(20 \mathrm{ml})$ was added and the solvent removed under reduced pressure at $50^{\circ} \mathrm{C}$. Aq. Ammonium hydroxide $(30 \mathrm{ml})$ was added again and the mixture stirred at room temperature for 5 hours and the solvent removed under reduced pressure at $50^{\circ} \mathrm{C}$. The residue was purified by ion-exchange chromatography on Dowex 50WX2-400 resin eluting with water. The product was visualized clearly by TLC (Rf 0.20 propan-1-ol-EtOAc-AcOH- $\mathrm{H}_{2} \mathrm{O}$ 1:1:1:1). After removal of solvent, a deliquescent white solid (12a) $(1.36 \mathrm{~g}, 80 \%)$ was obtained. The more stable ammonium salt was produced by redissolving the white solid in a few drops of $\mathrm{NH}_{4} \mathrm{OH}$ prior to removal of the solvent under reduced pressure. Data for (12a) ${ }^{1} \mathrm{H}$ NMR $\left(250 \mathrm{MHz}, \mathrm{D}_{2} \mathrm{O}\right) \delta: 5.22(1 \mathrm{H}, \mathrm{d}, J=8.0 \mathrm{~Hz}, \mathrm{H}-1)$, 3.87-3.67 (2H, m), 3.58-3.49 (2H, m), 3.42-3.20 (3H, m), $1.16\left(3 \mathrm{H}, \mathrm{dd}, J=7.5,16.0 \mathrm{~Hz}, \mathrm{CH}_{3}\right.$ of AEP); ${ }^{13} \mathrm{C}$ NMR $\left(63 \mathrm{MHz}, \mathrm{D}_{2} \mathrm{O}\right) \delta: 156.48(-\mathrm{O}(\mathrm{CO}) \mathrm{NH}), 95.37(\mathrm{C}-1), 76.73(\mathrm{CH}), 75.61$ $(\mathrm{CH}), 72.18(\mathrm{CH}), 69.84(\mathrm{CH}), 60.66(\mathrm{C}-6), 46.39(\mathrm{CH}, \mathrm{d}, J=153 \mathrm{~Hz}, \mathrm{CH}$ of AEP), 15.04 $\left(\mathrm{CH}_{3}\right.$ of $\left.\mathrm{AEP}\right)$.

f) To the $\beta$-galactoside (11b) $(4.44 \mathrm{~g}, 8.0 \mathrm{mmol})$ in anhydrous dichloromethane $(70 \mathrm{ml})$ was added trimethylsilylbromide ( $4.1 \mathrm{ml}, 31.7 \mathrm{mmol})$ and the solution was stirred overnight $(20 \mathrm{~h})$ at room temperature. Methanol $(20 \mathrm{ml})$ was added and the mixture stirred for 10 minutes. Aq. Ammonium hydroxide $(20 \mathrm{ml})$ was added and the solvent removed under reduced pressure at $50^{\circ} \mathrm{C}$. Aq. Ammonium hydroxide $(30 \mathrm{ml})$ was added again and the mixture stirred at room temperature for 3 hours and the solvent removed under reduced pressure at $50^{\circ} \mathrm{C}$. The residue was purified by ion-exchange chromatography on Dowex 50WX2-400 resin eluting with water. The product was visualized clearly by TLC (Rf 0.22 propan-1-ol-EtOAc-AcOH- $\mathrm{H}_{2} \mathrm{O}$ 1:1:1:1). After removal of the solvent, a deliquescent white solid (12b) $(2.40 \mathrm{~g}, 91 \%)$ was obtained. The more stable ammonium salt was produced by re-dissolving the white solid in a few drops of $\mathrm{NH}_{4} \mathrm{OH}$ and removal of the solvent under reduced pressure. Data for (12b) m.p $109-115^{\circ} \mathrm{C}$ dec; $[\alpha]^{20}{ }_{\mathrm{D}}+26.3^{\circ}\left(c 1, \mathrm{H}_{2} \mathrm{O}\right) ;{ }^{1} \mathrm{H}$ NMR $\left(250 \mathrm{MHz}, \mathrm{D}_{2} \mathrm{O}\right) \delta: 5.18(1 \mathrm{H}, \mathrm{d}, J=7.0$ 
$\mathrm{Hz}, \mathrm{H}-1), 3.88-3.46(7 \mathrm{H}, \mathrm{m}), 1.17\left(3 \mathrm{H}, \mathrm{dd}, J=7.5,16.0 \mathrm{~Hz}, \mathrm{CH}_{3}\right.$ of AEP); ${ }^{13} \mathrm{C}$ NMR (63MHz, $\left.\mathrm{D}_{2} \mathrm{O}\right)$ 8: $156.17\left(4^{\circ},-\mathrm{O}(\mathrm{CO}) \mathrm{NH}\right), 95.92(\mathrm{C}-1), 76.07(\mathrm{CH}), 72.64(\mathrm{CH}), 69.83(\mathrm{CH})$, $68.64(\mathrm{CH}), 61.08(\mathrm{C}-6), 44.97\left(\mathrm{CH}, \mathrm{d}, J=152 \mathrm{~Hz}, \mathrm{CH}\right.$ of AEP), $15.11\left(\mathrm{CH}_{3}\right.$ of AEP). 